\title{
Further observations on the effects of molassed sugar-beet feed on the eating quality of pig meat
}

\author{
J. D. Wood ${ }^{1}$, A. C. Longland ${ }^{2}$, M. Enser ${ }^{1}$ and G. R. Nute ${ }^{1}$ \\ 'Department of Meat Animal Science, School of Veterinary Science, University of Bristol, Langford, Bristol BS18 7DY \\ ${ }^{2} A F R C$, Institute for Grassland and Environmental Research, Shinfield, Reading
}

\section{Introduction}

Sugar-beet feed (SBF) is efficiently utilized by pigs (Longland, Wood, Enser, Carruthers and Keal, 1991) although some reports suggest that high levels in the diet will increase caecal fermentation and lead to high levels of skatole in meat (Lundstrom, Malmfors, Malmfors, Stern, Petersson, Mortensen and Sorensen, 1988). This would be expected to reduce eating quality because of 'off-odours' and flavours. Other work suggests that high fibre diets could result in low cholesterol concentrations in meat which could conceivably aid in marketing.

\section{Material and methods}

Forty pigs (equal numbers of male and female Large White $X$ Landrace type) were given four diets in groups of 10 . All diets had the same digestible energy and lysine content $(13.8 \mathrm{MJ}$ and $9.5 \mathrm{~g} / \mathrm{kg}$ respectively) with SBF replacing barley as SBF increased from 0 to $450 \mathrm{~g} / \mathrm{kg}$. The growth period was 20 to $77.5 \mathrm{~kg}$ live weight and feeding was ad libitum.

After slaughter, samples of backfat were taken from the last rib region for fatty acid, cholesterol, skatole and indole measurements and loin joints were taken and conditioned for 6 days at $1^{\circ} \mathrm{C}$. These were then frozen prior to taste panel analysis. For this, $2 \cdot 5-\mathrm{cm}$ thick steaks were griddled to an internal temperature of $80^{\circ} \mathrm{C}$ and 10 trained taste panellists scored eating quality traits on 1 to 8 scales increasing in intensity.

\section{Results and discussion}

Results for $\mathrm{P}_{2}$ fat thickness and the fatty acid composition of backfat are shown in Table 1. As the concentration of SBF increased, $\mathrm{P}_{2}$ declined, the water concentration in backfat increased and the

+ Present address: Institute for Grassland and Environmental Research, Welsh Plant Breeding Station, Aberystwyth SY23 3EB. concentration of linoleic acid $(\mathrm{C} 18: 2)$ in backfat decreased. This was due to higher levels of soya oil in the low SBF diets (see Longland et al., 1991). Normally the concentration of C18:2 increases as fat thickness declines.

Results for cholesterol, skatole and indole concentrations in backfat are shown in Table 2. There was no effect of SBF on cholesterol but skatole concentration decreased as SBF increased. All values were below the level of $0.2 \mathrm{mg} / \mathrm{kg}$ considered to represent the point above which taint problems occur (Lundstrom et al., 1988) or the value of 0.12 found in a recent Danish report to cause low eating quality in pigs given high levels of peas (Madsen, Osterballe, Mortensen, Bejerholm and Barton, 1990).

Results for eating quality are shown in Table 3. In fat tissue both pork odour intensity and abnormal odour intensity tended to decline as SBF increased but these effects were not significant. In lean, pigs given the $300 \mathrm{~g} / \mathrm{kg}$ SBF diet had the palest colour and the most

Table 1 Effects of sugar-beet feed (SBF) on $P_{2}$ and the chemical composition of backfat

\begin{tabular}{|c|c|c|c|c|c|c|}
\hline & \multicolumn{4}{|c|}{$\mathrm{SBF}(\mathrm{g} / \mathrm{kg})$} & \multirow[b]{2}{*}{ s.e.d. } & \multirow[b]{2}{*}{ Significance } \\
\hline & 0 & 150 & 300 & 450 & & \\
\hline$P_{2}(\mathrm{~mm})$ & $13 \cdot 7$ & $10 \cdot 4$ & $10 \cdot 8$ & 9.7 & $1 \cdot 12$ & * \\
\hline $\begin{array}{c}\text { Fat water } \\
\text { content } \\
(\mathrm{g} / \mathrm{kg})\end{array}$ & 167 & 183 & 216 & 226 & $20 \cdot 5$ & $*$ \\
\hline \multicolumn{7}{|c|}{$\begin{array}{l}\text { Backfat fatty } \\
\text { acids }(\mathrm{g} / \mathrm{kg})\end{array}$} \\
\hline C14:0 & 16 & 16 & 16 & 16 & 0.5 & \\
\hline C16:0 & 247 & 246 & 251 & 252 & $3 \cdot 8$ & \\
\hline C16:1 & 26 & 27 & 29 & 30 & 1.8 & * \\
\hline C18:0 & 134 & 125 & 133 & 133 & $4 \cdot 4$ & * \\
\hline C18: 1 & 382 & 363 & 395 & 367 & 11.9 & $*$ \\
\hline C18:2 & 156 & 166 & 135 & 126 & $10 \cdot 3$ & $*$ \\
\hline C18:3 & 17 & 20 & 15 & 14 & $1 \cdot 3$ & * \\
\hline
\end{tabular}


Table 2 Effects of sugar-beet feed (SBF) on cholesterol, skatole and indole concentrations in backfat (mg/ $\mathrm{kg}$ )

\begin{tabular}{lcccccc}
\hline & \multicolumn{2}{c}{ SBF $(\mathrm{g} / \mathrm{kg})$} & & \\
\cline { 2 - 6 } & 0 & 150 & 300 & 450 & s.e.d. & Significance \\
\hline Cholesterol & 661 & 685 & 658 & 660 & $37 \cdot 3$ & 0.0077 \\
Indoles & 0.023 & 0.022 & 0.022 & 0.012 & 0.0138 & $*$ \\
Skatole & 0.069 & 0.064 & 0.038 & 0.036 & $*$ \\
\hline \hline
\end{tabular}

Table 3 Eating quality of pork chops (mean scores of 10 trained taste panellists using 1 to 8 scales)

\begin{tabular}{|c|c|c|c|c|c|c|}
\hline & \multicolumn{4}{|c|}{$\mathrm{SBF}(\mathrm{g} / \mathrm{kg})$} & \multirow[b]{2}{*}{ s.e.d. } & \multirow[b]{2}{*}{ Significance } \\
\hline & 0 & 150 & 300 & 450 & & \\
\hline \multicolumn{7}{|l|}{ Fat } \\
\hline $\begin{array}{l}\text { Pork odour } \\
\text { intensity }\end{array}$ & $4 \cdot 50$ & $4 \cdot 44$ & $4 \cdot 34$ & $4 \cdot 36$ & $0 \cdot 204$ & \\
\hline $\begin{array}{l}\text { Abnormal } \\
\text { odour }\end{array}$ & & & & & & \\
\hline intensity & 1.96 & 1.91 & $1 \cdot 77$ & $1 \cdot 76$ & $0 \cdot 184$ & \\
\hline \multicolumn{7}{|l|}{ Lean } \\
\hline Colour & $4 \cdot 62$ & $4 \cdot 49$ & $4 \cdot 09$ & $4 \cdot 45$ & $0 \cdot 121$ & $* * *$ \\
\hline Tenderness & 3.82 & $4 \cdot 25$ & $4 \cdot 76$ & $3 \cdot 94$ & $0 \cdot 157$ & $* * *$ \\
\hline Juiciness & $4 \cdot 19$ & $4 \cdot 20$ & $4 \cdot 31$ & $4 \cdot 12$ & $0 \cdot 147$ & \\
\hline \multicolumn{7}{|c|}{ Pork flavour } \\
\hline intensity & $4 \cdot 72$ & $4 \cdot 50$ & $4 \cdot 40$ & 4.09 & $0 \cdot 180$ & $* *$ \\
\hline Abnormal & & & & & & \\
\hline $\begin{array}{l}\text { flavour } \\
\text { intensity }\end{array}$ & 2.62 & $2 \cdot 32$ & $2 \cdot 22$ & $2 \cdot 15$ & $0 \cdot 218$ & \\
\hline \multicolumn{7}{|l|}{ Overall } \\
\hline liking & $4 \cdot 46$ & $4 \cdot 70$ & 4.96 & $4 \cdot 40$ & 0.168 & $* *$ \\
\hline
\end{tabular}

tender meat. They also had the highest score for overall liking. Pork flavour intensity decreased with SBF inclusion and abnormal flavour intensity tended also to decrease although this effect was not significant.

\section{Conclusions}

Increasing the concentration of SBF from 0 to $450 \mathrm{~g} / \mathrm{kg}$ had no effect on the concentration of cholesterol in pig backfat but reduced the concentration of skatole. Far from reducing eating quality traits as was expected, increasing SBF was associated with reduced abnormal odours and flavours. The highest tenderness and overall liking scores were given to meat from pigs given $300 \mathrm{~g} / \mathrm{kg}$ SBF.

\section{References}

Longland, A. C., Wood, J. D., Enser, M. B., Carruthers, J. C. and Keal, H. D. 1991. Effects of growing pig diets containing $0,150,300$ or $450 \mathrm{~g}$ molassed sugar beet feed per $\mathrm{kg}$ on carcass and meat eating quality. Animal Production 52: 559-560.

Lundstrom, K., Malmfors, B., Malmfors, G., Stern, S., Petersson, H., Mortensen, A. B. and Sorensen, S. E. 1988. Skatole, androstenone and taint in boars fed two different diets. Livestock Production Science 18: 55-67.

Madsen, A., Osterballe, R., Mortensen, H. P., Bejerholm, C. and Barton, P. 1990. The influence of feeds on meat quality of growing pigs 1 . Report 673, National Institute of Animal Science, Denmark. 